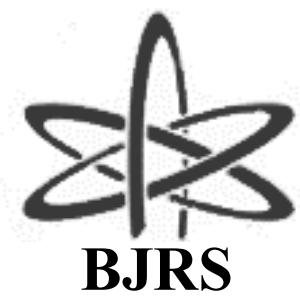

BRAZILIAN JOURNAL
OF
RADIATION SCIENCES
07-02B (2019) 01-18

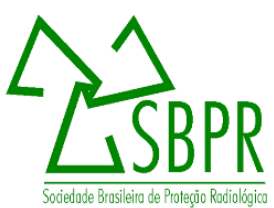

\title{
Brayton cycle numerical modeling using the RELAP5-3D code, version 4.3.4
}

\author{
E. P. Longhini ${ }^{\mathrm{a}, \mathrm{b}}$; P.D. C. Lobo ${ }^{\mathrm{a}}$; L. N. F. Guimarães ${ }^{\mathrm{a}, \mathrm{b}}$; F. A. B. Filho ${ }^{\mathrm{a}}$; G. B. Ribei- \\ $\mathrm{ro}^{\mathrm{a}, \mathrm{b}}$ \\ ${ }^{a}$ Divisão de Energia Nuclear, Instituto de Estudos Avançados, 12228-001, São José dos Campos-SP, Brasil \\ ${ }^{b}$ Pós-Graduação em Ciências e Tecnologias Espaciais, Instituto Tecnológico de Aeronáutica, 12228-900, São José \\ dos Campos-SP, Brasil \\ edu_longhini@yahoo.com.br
}

\begin{abstract}
This work contributes to enable and develop technologies to mount fast microreactors, to generate heat and elec tric energy, for the purpose to warm and to supply electrically spacecraft equipment and, also, the production of nuclear space propulsion effect. So, for this purpose, the Brayton Cycle demonstrates to be an optimum approach for space nuclear power. The Brayton thermal cycle gas has as characteristic to be a closed cycle, with two adiabatic processes and two isobaric processes. The components performing the cycle's processes are compressor, turbine, heat source, cold source and recuperator. Therefore, the working fluid's mass flow runs the thermal cycle that converts thermal energy into electrical energy, able to use in spaces and land devices. The objective is numerically to model the Brayton thermal cycle gas on nominal operation with one turbomachine composed for a radial-inflow compressor and turbine of a $40.8 \mathrm{kWe}$ Brayton Rotating Unit (BRU). The Brayton cycle numerical modeling is being performed with the program RELAP5-3D, version 4.3.4. The nominal operation uses as working fluid a mixture $40 \mathrm{~g} / \mathrm{mole} \mathrm{He}-\mathrm{Xe}$ with a flow rate of $1.85 \mathrm{~kg} / \mathrm{s}$, shaft rotational speed of $45 \mathrm{krpm}$, compressor and turbine inlet temperature of $400 \mathrm{~K}$ and $1149 \mathrm{~K}$, respectively, and compressor exit pressure $0.931 \mathrm{MPa}$. Then, the aim is to get physical corresponding data to operate each cycle component and the general cycle on this nominal operation.
\end{abstract}


Keywords: relap5, brayton cycle, nuclear space power.

\section{INTRODUCTION}

Power systems for space exploration are the establishment of man's extraterrestrial civilization. These systems must be reliable, abundant and portable energy for man's permanent presence in outer space. For the power systems development, the main characteristics are the availability of compact energy sources for power and propulsion, the ability to process materials anywhere in the Solar System and creation of permanent human habitats in outer space (ANGELO JR.; BUDEN, 1985).

To comply this objective, the power systems shall have high electric-power level, compact size and long operation lifetimes (ANGELO JR.; BUDEN, 1985). Therefore, many power systems are being developed to these purposes as solar power systems in which sunlight is converted to electricity by using solar cells made either silicon or gallium arsenide (STINE, 1981) and stored by nickel-cadmiun battery (SNYDER, 1961), chemical power systems using chemical elements as liquid hydrogen, liquid oxygen, hydrazine and others or experimental methods as cryogenically fueled (SNYDER, 1961) and nuclear power systems involving the use of thermal energy liberated by nuclear processes as decay of radioisotopes, controlled fission of heavy nuclei or controlled fusion approach with either thermodynamics cycles - Brayton, Rankine, Stirling cycles - or thermoelectric and thermionic systems for conversion from thermal energy to power energy (ANGELO JR.; BUDEN, 1985).

The nuclear power systems have been studied as the principal power system for future interplanetary exploration missions as Jupiter missions, Mars and Lunar Outposts (BAKER, 2004; GALLO; EL-GENK, 2009; JOYNER II; FOWLER; MATTHEWS, 2003; MASON, 2001; RIBEIRO; BRAZ FILHO; GUIMARÃES, 2015; WRIGHT; FULLER; LIPINSKI, 2005). Their advantages are compact size, low to moderate mass, long operation lifetime, operation in hostile environments, operation independent of the distance from the Sun or of the orientation to the Sun, high system reliability and autonomy (ANGELO JR.; BUDEN, 1985). Among the conversions systems for nuclear power - Brayton cycle, Rankine cycle, Stirling cycle, thermoelectric 
and thermionic systems -, Brayton cycle in closed type is the most promising energy conversion for space power systems (RIBEIRO; BRAZ FILHO; GUIMARÃES, 2015).

\subsection{CLOSED BRAYTON CYCLE}

Brayton Cycle demonstrates to be an optimum approach for space nuclear power requirements that range from ten to hundreds kilowatts of power and it can use advanced high temperature materials, lightweight radiators (MASON, 2001) and it can be high energy efficiency and high power output to radiator area ratio (RIBEIRO; BRAZ FILHO; GUIMARÃES, 2015).

A generic Brayton Cycle used for space nuclear power is demonstrated at the Fig. 1. This cycle is closed type with two adiabatic process and two isentropic process. The cycle components are a gas turbine, compressor, generator, recuperator, sink and source. It uses the heat-transfer process, that is, heat transferred, either directly or via a second fluid, from the fuel in the nuclear reactor to the working fluid in the gas turbine (VAN WYLEN; SONNTAG, 1978 ou 1994). Thus, the turbine work rotates the shaft, it drives the compressor and working excess is available as electrical power output, via generator. In the hot leg recuperator, part of the turbine outlet energy is transferred to the fluid in the compressor exit (RIBEIRO; BRAZ FILHO; GUIMARÃES, 2015). Energy hot leg recuperator outlet is rejected from the fluid to the surroundings by radiator. The compressor and cold leg recuperator (by energy transferred for hot leg recuperator) supply energy to fluid, closing the cycle.

Figure 1: Brayton cycle for space nuclear power 
(Fonte: BRADHORST JR, [s.d.])

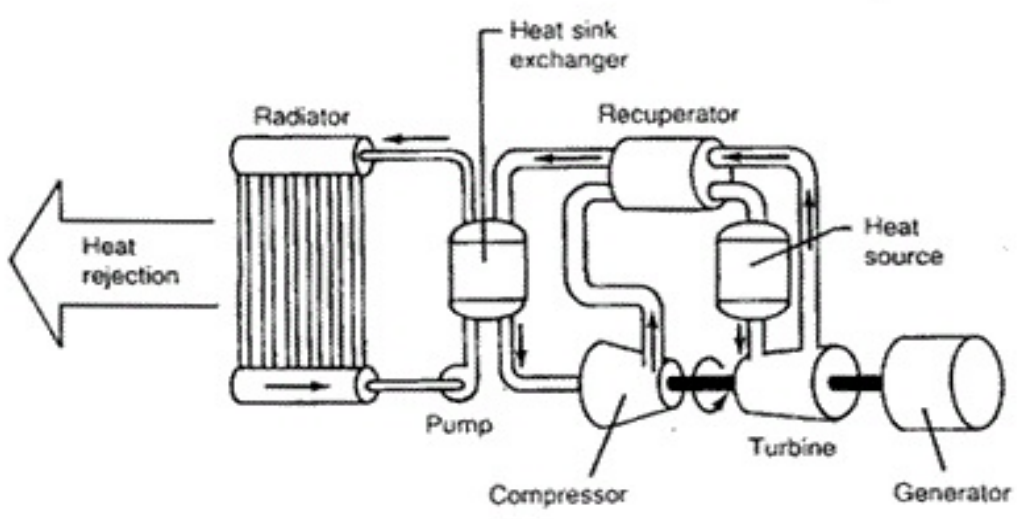

A Brayton Rotating Unit (BRU) which was designed and manufactured by NASA has a singleshaft turbine-compressor-generator package, with the rotating component of Brayton power system being designed to operate on self-acting gas bearings and on a binary He-Xe mixture. The BRU has high efficiency in the turbomachinery components, about $80-90 \%$ for turbine and compressor (WONG; KLASSEN; EVANS, 1971).

So, the Closed Brayton Cycle (CBC) reactor power system with BRU is most suitable to use in conjunction with gas-cooled space reactors. The resulting thermal efficiency of the power system could be well in excess $20 \%$, depending on the reactor exit temperature and on the design of the BRU compressor and turbine. Also, the He-Xe working fluid with molecular weights of 15-40 $\mathrm{g} /$ mole reduces the size of the BRU for energy conversion (GALLO; EL-GENK, 2009).

\subsection{RELAP5-3DC}

RELAP5-3D C consists of a variety of generic models that are used to build power systems. Specific applications of the code have included simulations of transients in light water reactor (LWR) systems, such as loss of coolant, and operational transients such as loss of feedwater, loss of offsite power, station blackout, and turbine trip (THE RELAP5-3D CODE DEVELOPMENT TEAM, 2001 ou 2013). 
The generic models are separate in the categories as hydrodynamic models - the pipe, branch, single-volume, single-junction, compressor, turbine and others components - heat structures, reactor kinetics model and etc.

The hydrodynamic simulation is based on a one-dimensional model and a multi-dimensional model of the transient flow for a vapor-liquid-noncondesable gas mixture. The numerical solution scheme used results in a system representation using control volumes connected by junctions. For vapor/liquid system, three equations (i.e. mass, momentum and energy equations) govern the model, each phase has its own set of equations and for interfacial interactions they are represented as source terms (BRAZ FILHO et al., 2017).

The Eq. 1 represents the mass conservation for vapor phase under a one-dimensional transient:

$$
\frac{\partial}{\partial t}\left(\rho_{v}\right)+\frac{1}{A} \frac{\partial}{\partial x}\left(\rho_{v} u_{v} A_{v}\right)=0
$$

where $\rho$ is density, $\mathrm{u}$ is velocity and $\mathrm{A}$ is the channel flow area. Eq. 2 is the momentum conservation equation for vapor phase:

$$
\rho_{v} A \frac{\partial u_{v}}{\partial t}+\frac{1}{2} \rho_{v} A \frac{\partial u_{v}^{2}}{\partial x}=-A \frac{\partial P}{\partial x}
$$

where $\mathrm{P}$ is the pressure (THE RELAP5-3D CODE DEVELOPMENT TEAM, 2001). The Eq. 3 is the energy conservation equation for vapor phase:

$$
\frac{\partial}{\partial t}\left(\rho_{v} U_{v}\right)+\frac{1}{A} \frac{\partial}{\partial x}\left(\rho_{v} U_{v} u_{v} A_{v}\right)=-\frac{P}{A} \frac{\partial}{\partial x}\left(u_{v} A\right)
$$

where $U$ is the specific internal energy (THE RELAP5-3D CODE DEVELOPMENT TEAM, 2001 ou 2013).

Heat structures provided in RELAP5-3D C permit calculation of the heat transferred across solid boundaries of hydrodynamic volumes. For one-dimensional heat conduction, heat structures are 
represented using rectangular, cylindrical or spherical geometry. Temperature-dependent and space-dependent thermal conductivities and volumetric heat capacities are provided in tabular or functional form either form built-in or user-supplied data (THE RELAP5-3D CODE DEVELOPMENT TEAM, 2001).

The Code HEAT-1, developed at the Idaho National Laboratory (INL), is used to the one-dimensional heat conduction model. It uses finite differences to advance the heat conduction solutions. In which, each mesh interval may contain a different mesh spacing, a different material or both. The time-dependence of the heat source can be obtained from reactor kinetics, one of several tables of power versus time, or a control system variable (THE RELAP5-3D CODE DEVELOPMENT TEAM, 2001). The integral form of the heat conduction equation is:

$$
\iiint_{V} \rho C_{P}(T, \bar{x}) \frac{\partial T}{\partial t}(\bar{x}, t) d V=\iint_{S} k(T, \bar{x}) \bar{\nabla} T(\bar{x}, t) \cdot d \bar{s}+\iiint_{V} S(\bar{x}, t) d V
$$

where $\rho C_{p}$ is the volumetric heat capacity, $\bar{x}$ is space coordinates, $V$ is volume, $T$ is temperature, $\mathrm{k}$ is thermal conductivity, $\mathrm{s}$ is the surface and $\mathrm{S}$ is the internal volumetric heat source.

Further details about RELAP5-3D C can be found in the Idaho National Laboratory (2013) code manuals.

\subsection{OBJECTIVE}

The Institute for Advanced Studies (IEAv) is conducting a program called TERRA (TEcnologia de Reatores Rápidos Avançados). It has as objective to enable and to develop technologies to project and to make fast microreactors, to generate heat and electric energy, for the purpose to warm and to feed electrically spacecraft equipment and, also, to produce nuclear space propulsion effect.

But, as short-term objective, TERRA project aims to use the RELAP5-3D (C) for thermal circuit numerical modeling. Hence, the thermodynamics analyzes are to be achievable, enabling rework 
to improve cycle efficiency, to optimize cycle fundamentals parameters and to operate with security. After that, the project can begin the development and building of a thermal circuit to achieve its own objectives mentioned above.

Therefore, this work has as focus a numerical modeling of a thermal circuit gas, the Closed Brayton Cycle (CBC) type using the RELAP5-3DC software with a nominal operation and features established by (GALLO; EL-GENK, 2009). It will allow to obtain temperature from transient-state to steady-state of the compressor, turbine, sink, source and recuperator, and also power values at the turbine, compressor and generator. Besides, the compressor and turbine polytrophic efficiency and the cycle efficiency.

\section{METHODOLOGY}

The nominal operation was calculated by B. M. Gallo and M. S. El-Genk (GALLO; EL-GENK, 2009), where a Submersion-Subcritical Safe Space $\left(S^{\wedge} 4\right)$ reactor is the heat source to three direct CBC loops, each one with a separate BRU and heat rejection radiator panels, Fig. 2.

Figure 2: $A C B C$-space power system nominal operation parameters and layout (Fonte: GALLO; EL-GENK, 2009)

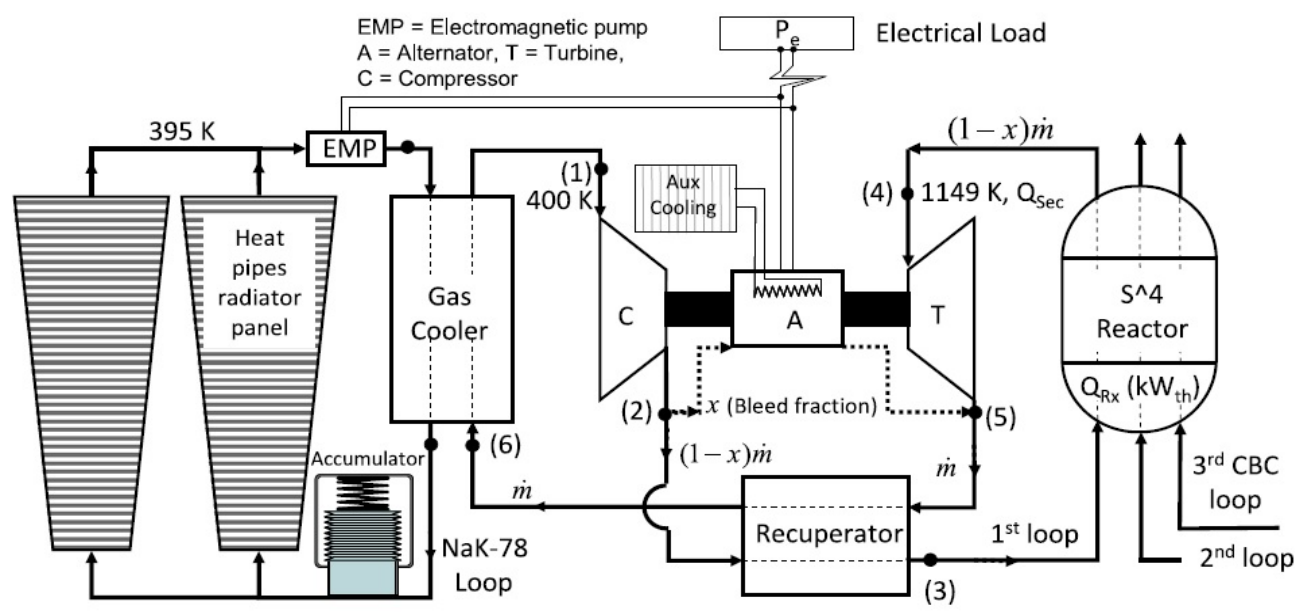


The reactor is separate in three sectors. Each sector nominally generates $157 \mathrm{kWt}(\mathrm{Qr})$ and it is coupled in a separate CBC loop with one BRU. The reactor supplies heat to He-Xe working fluid, which is also coolant reactor. Hence, BRU generates $40.8 \mathrm{kWe}$ when operating at compressor and turbine inlet temperatures of $400 \mathrm{~K}$ and $1149 \mathrm{~K}$ and shaft rotating speed of $45 \mathrm{krpm}$ (GALLO; EL-GENK, 2009).

\subsection{Closed Brayton Cycle numerical modeling}

The Brayton cycle components in the RELAP5-3DC are listed in Fig. 3. Thus, the source is 100 component, the turbine component is 101 , recuperator hot leg is 102 component, sink is 103 component, compressor is 104 component, recuperator cold leg is 105 component and branches are 345-350 components. The heat structures are represented by diagonal lines in components $100,102,103$ and 105.

Figure 3: Brayton Cycle modelling map

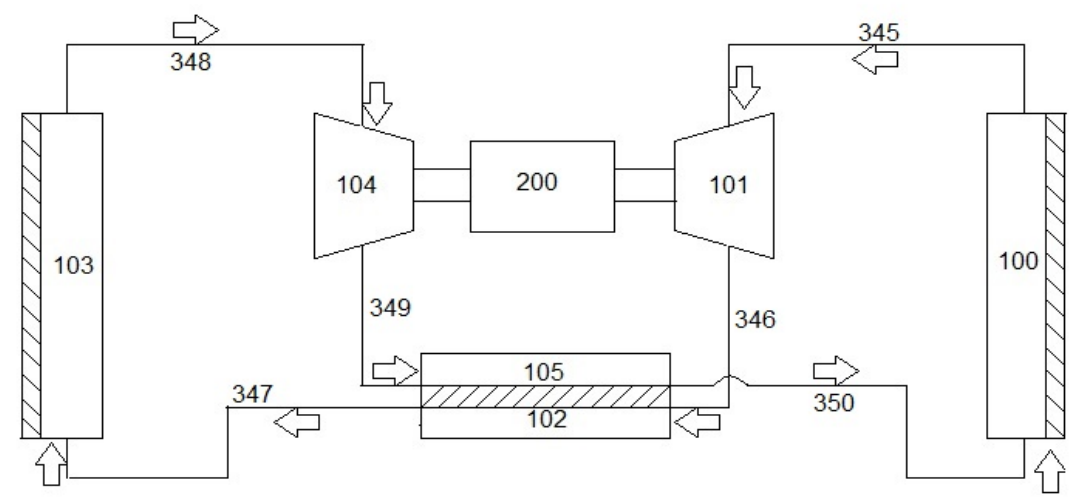

\subsubsection{Source}

The heat source supplies $157 \mathrm{kWt}$ power and thermodynamics initial conditions, pressure and temperature, are, respectively, $926.0 \mathrm{kPa}$ and $981.8 \mathrm{~K}$ for one Brayton cycle [4]. 
For the RELAP5-3D heat structure simulation, the heat source was considered as a heat exchanger, which design was calculated applying energy balance equations. Using $Q_{r}$ equal to 157 $\mathrm{kWt}$, length of each tube as 1.5 meters, $\mathrm{r}_{2}$ (right boundary condition) equal to $5 \mathrm{~mm}, \mathrm{r}_{1}$ (left boundary condition) as $4.3503 \mathrm{~mm}$, it could be obtained the number of tubes (363) and flow area of each one. The tubes material was considered stainless steel which has as surface convection coefficient $(\mathrm{k})$ equal to $13.81 \mathrm{~W} / \mathrm{m}^{2} \mathrm{~K}$.

\subsubsection{Sink}

In reference (GALLO; EL-GENK, 2009), the sink has an own cycle with Gas Cooler, changing heat with Brayton Cycle. The radiator panel, changes heat with space. The cycle has NaK-78 as working fluid. But, in this simulation it was considered only the Gas Cooler as a heat exchanger with ambient. The characteristics of the Gas Cooler were: $115.1 \mathrm{kWt}$ power and thermodynamics initial conditions, pressure and temperature, respectively, $635.5 \mathrm{kPa}$ and $520.0 \mathrm{~K}$.

The application of heat and mass transfer equations yields to the results of 479 tubes, each tube length of $1.5 \mathrm{~m}$, radius of $3.4819 \mathrm{~mm}$ and thickness of $1.5181 \mathrm{~mm}$.

\subsubsection{Recuperator}

The recuperator is a counterflow heat exchanger type, where the initial conditions for pressure and temperature, respectively, are $635.5 \mathrm{kPa}$ and $1008 \mathrm{~K}$ for hot leg and $931.6 \mathrm{kPa}$ and $483.3 \mathrm{~K}$ for cold leg. Assuming the hot or cold mass flow rate with value of the $1.85 \mathrm{~kg} / \mathrm{s}$ or $1.811 \mathrm{~kg} / \mathrm{s}$ and $\mathrm{Cp}$ equal $0.51 \mathrm{~kJ} / \mathrm{kgK}$, the total rate of heat transfer, Eq. 6 , to the hot or cold fluids is about $460.4 \mathrm{~kW}$.

$$
Q=\dot{m}_{h(c)} c_{p, h(c)}\left(T_{h(c), i(o)}-T_{h(c), o(i)}\right)
$$

Where the subscript $\mathrm{h}$ refers to the hot fluids, $\mathrm{c}$ to the cold fluids whereas the subscript $\mathrm{i}$ and $\mathrm{o}$ designates the inlet and outlet fluid conditions [16]. The total heat transfer surface area was cal- 
culated assuming the value of $U$ as $200 \mathrm{~W} / \mathrm{m}^{2} \mathrm{~K}$. Using Eq. 6, the results are $7.40 \mathrm{~m}^{2}$, and $1477.54 \mathrm{~W} / \mathrm{K}$ for $\mathrm{UA}$.

where $\Delta T=\frac{\Delta T_{2}-\Delta T_{1}}{\ln \left(\Delta T_{2} / \Delta T_{1}\right)}$ with $\quad \Delta T_{1} \equiv T_{h, 1}-T_{c, 1}=T_{h, i}-T_{c, 0} \quad$ and $\Delta T_{2} \equiv T_{h, 2}-T_{c, 2}=T_{h, 0}-T_{c, i} \quad($ INCROPERA; DEWITT, 2011).

Applying the balance equations as before for the sink and source cases and considering $1.5 \mathrm{~m}$ for length and $5 \mathrm{~mm}$ for $\mathrm{r}_{2}$, it was found 360 tubes, $4.3557 \mathrm{~mm}$ for $\mathrm{r}_{1}$ and $0.6449 \mathrm{~mm}$ for thickness.

The recuperator at the Relap5-3D C ambient has two pipes in opposite directions, connected with a heat structure, where the pipe with cold leg has diameter greater than pipe with hot leg. And the pipes are divided in ten parts, each part has one-ten of the length with diameter equal, the total flow area was calculated with the one tube flow area times 360 tubes. For heat structure transfers from hot leg to cold leg a convective boundary condition was used where the total wall heat transfer coefficient was obtained from Wall Heat Transfer Package 1 (THE RELAP5-3D CODE DEVELOPMENT TEAM, 2005 ou 2013).

\subsubsection{Turbomachine}

The turbomachine was simulated with RELAP5-3DC's compressor model and turbine model, where they connected with a generator through a shaft.

\subsubsection{Compressor}

The compressor simulation was based on J. F. Fisher (FISHER; DAVIS, 2005) using G. B. Ribeiro (RIBEIRO; BRAZ FILHO; GUIMARÃES, 2015) for compressor map performance. 
With the efficiency and mass flow equations from (RIBEIRO; BRAZ FILHO; GUIMARÃES, 2015), the performance curve at a given relative corrected speed was extrapolated so that the entire range of allowed operation could be simulated (FISHER; DAVIS, 2005).

The compressor has two junctions which connect to 348 and 349 components. The junction area is minimum volume flow area of the adjoining volume. The used control flags specify the singlevelocity momentum equation option. The mass flow is $1.85 \mathrm{~kg} / \mathrm{s}$ (GALLO; EL-GENK, 2009).

Using BRU's compressor data, Fig. 3, flow area and radial length are calculated, respectively, $5.2 \cdot 10^{-3} \mathrm{~m}^{2}$ and $110.0 \mathrm{~mm}$. For compressor description, the rated stagnation fluid density was calculated by Eq. 7 (BALACHANDRAN, 2006):

$$
\rho_{0, R}=\frac{P_{0}}{R T_{0}}
$$

where $\mathrm{R}$ is ideal gas constant, $\mathrm{P}_{0}$ initial pressure and $\mathrm{T}_{0}$ initial temperature. The rated stagnation sonic speed was calculated by Eq. 8 (BALACHANDRAN, 2006) as follows:

$$
a_{0, R}=\sqrt{\gamma R T_{0}}
$$

where $\gamma$ is heat capacity ratio with value of 1.667 .

\subsubsection{Turbine}

Turbine model has one junction connected to 345 component. The junction area is minimum volume flow area of the adjoining volume. The used control flags specify the single-velocity mo- 
mentum equation option. The mass flow is $1.811 \mathrm{~kg} / \mathrm{s}$ (GALLO; EL-GENK, 2009). The turbine exit is 346 component, which connects turbine to recuperator hot fluid pipe.

For BRU's turbine data, Fig. 3, the hydraulic diameter is $74.4 \mathrm{~mm}$, so the flow area is about $0.0044 \mathrm{~m}^{2}$ and the radial length is $101.6 \mathrm{~mm}$. The wall roughness is $1.0 \cdot 10^{-9}$ times hydraulic diameter.

A turbine type-1 was considered. It belongs to a general impulse-reaction stage group, where design reaction fraction is 0.5 , because this turbine is a reaction turbine (THE RELAP5-3D CODE DEVELOPMENT TEAM, 2001 ou 2013). 94.1\% is the actual efficiency at the maximum efficiency design point.

\subsubsection{Shaft}

Component's number for shaft is 200 . It is always connected to turbine, compressor and generator. The material considered for shaft is steel. The moment of inertia is $0.03878 \mathrm{~kg} \cdot \mathrm{m}^{2}$, and, according to (GALLO; EL-GENK, 2009), the rotational velocity is $45 \mathrm{krpm}$.

\subsubsection{Working fluid}

The $40 \mathrm{~g} / \mathrm{mol} \mathrm{He-Xe} \mathrm{was} \mathrm{used} \mathrm{as} \mathrm{working} \mathrm{fluid,} \mathrm{where} \mathrm{He} \mathrm{composes} 72 \%$ and Xe composes $28 \%$. The heat capacity at constant pressure is $0.51 \mathrm{~kJ} / \mathrm{kgK}$.

\section{RESULTS AND DISCUSSIONS}

In the first seconds, about between 0 and 5 seconds, after turning on the cycle, BRU begins to work, the turbine power is available to compressor and generator, as shows the Fig. 4. The compressor and net power increase rapidly together the turbine power. And between 10 and 110 seconds, when the powers are in transient-state, the compressor power increases slowly from 87.42 
$\mathrm{kW}$ to $94.89 \mathrm{KW}$, the net power decreases slowly from $34.86 \mathrm{~kW}$ to $32.11 \mathrm{~kW}$, the opposite performance is caused because the compressor consumes more turbine power than generator.

Figure 4: Turbine, Compressor and net power transient-state

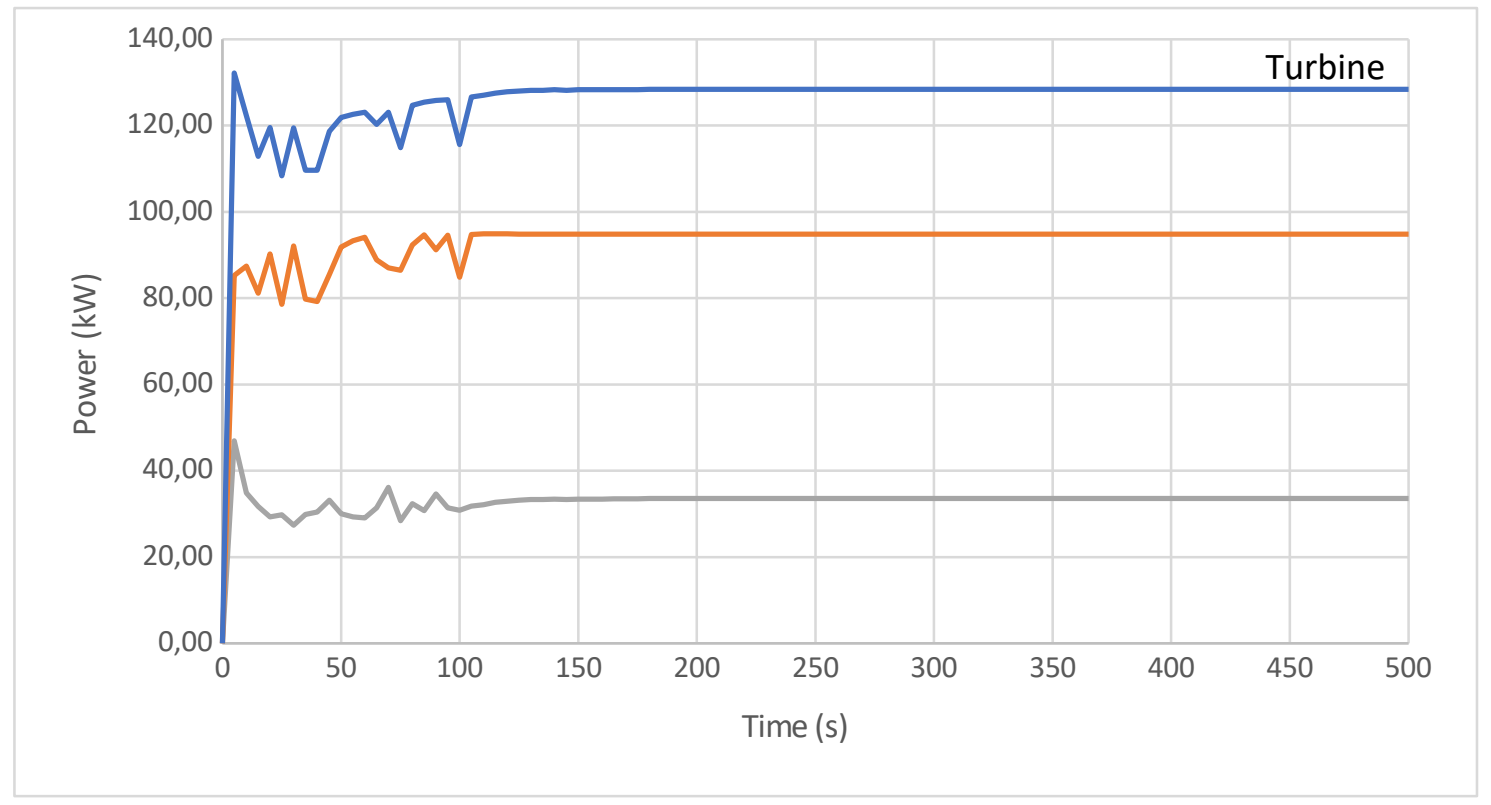

For turbine, the power steady-state is founded about 180 seconds with value of $128,38 \mathrm{~kW}$, for compressor and generator about 355 seconds with values of $94,85 \mathrm{~kW}$ and $33,53 \mathrm{~kW}$. At this point, it observes that compressor power consumes about $74 \%$ of turbine power.

The turbine and compressor exit temperatures transient-state are showed in Fig. 5. For turbine, the temperature is transient-state between 0 and 180 seconds with few variations in relation the initial value of $1001.9 \mathrm{~K}$. And compressor exit temperature increase quickly, between 0 and 5 seconds, from $480.5 \mathrm{~K}$ to $620.1 \mathrm{~K}$. Between 10 and 295 seconds, compressor exit temperature is in transient-state. The temperature value in steady-state for turbine is $1000.1 \mathrm{~K}$ and for compressor is $573.4 \mathrm{~K}$.

Figure 5: Turbine and Compressor exit temperatures transient-state 


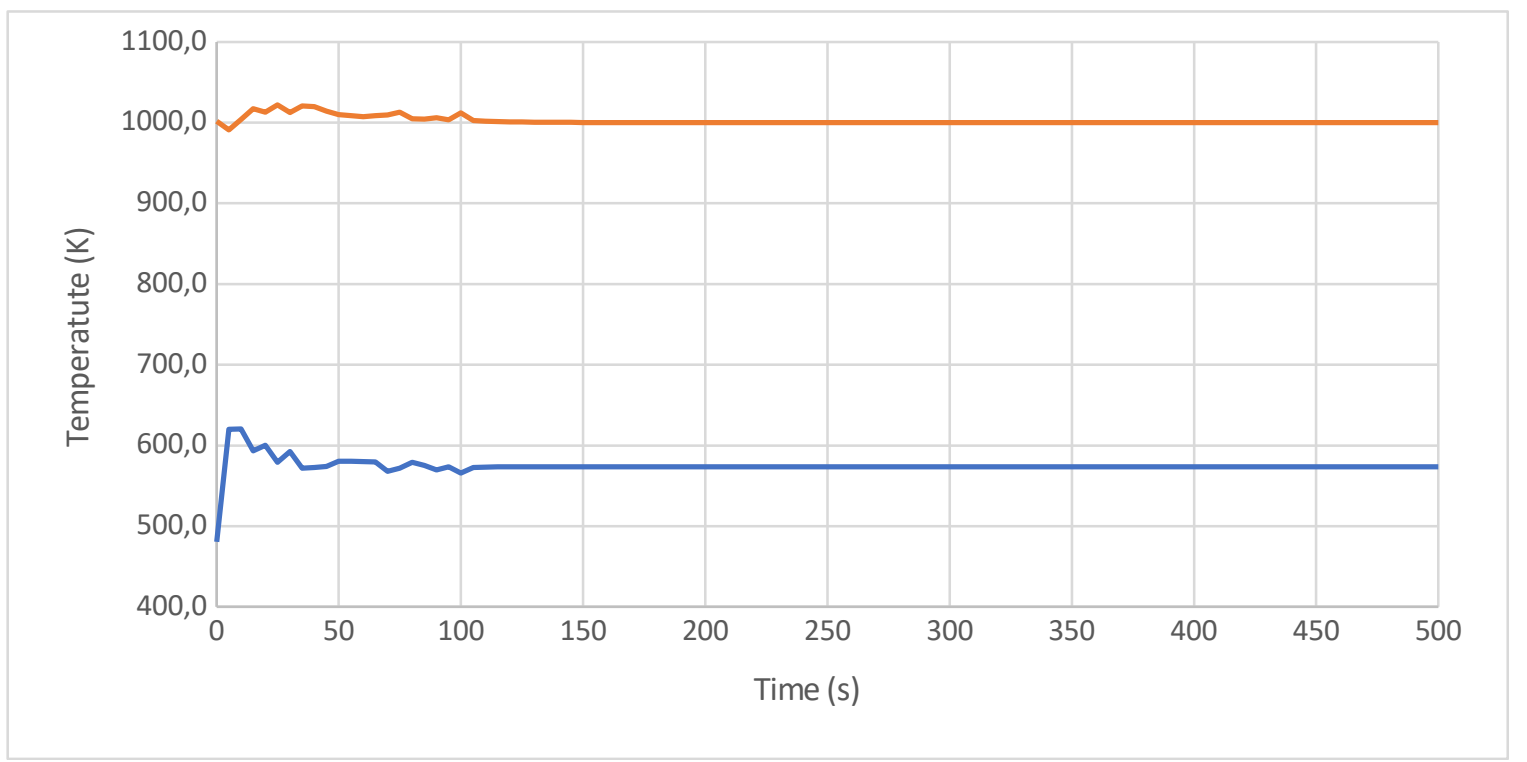

The exit temperatures performance for source, sink and recuperator hot (and cold) leg are show in the Fig. 6. When the cycle is started, the temperature begins the transient-state for all components. For source and sink, the temperature increases and decreases, respectively, quickly between 0 e 5 seconds. For source, from $971.5 \mathrm{~K}$ to $1134.3 \mathrm{~K}$ and for sink, from $611.4 \mathrm{~K}$ to 529.7 K.

The temperatures transient-state finish in time different periods for the components, for source in 145 seconds with temperature value of $1139,1 \mathrm{~K}$, for sink in 255 seconds with temperature value of $472.9 \mathrm{~K}$, for recuperator hot leg in 250 seconds with temperature value of $604.3 \mathrm{~K}$, for recuperator cold leg in 310 seconds with temperature value of $967.8 \mathrm{~K}$. 
Figure 6: Hot leg recuperator, Cold leg recuperator, sink and source exit temperatures transient-state

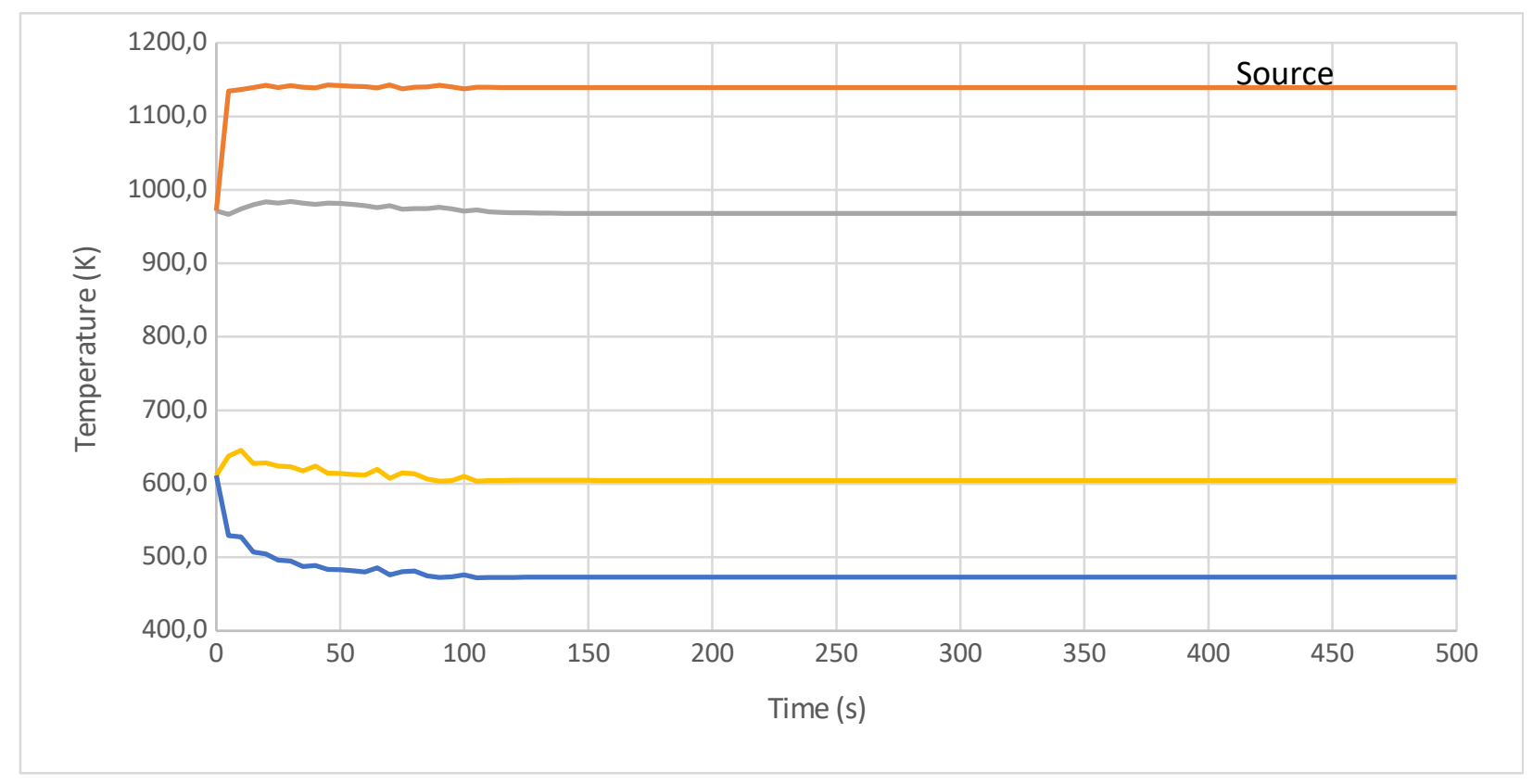

The result for compressor polytrophic efficiency, in the steady-state, is $84.1 \%$ and for turbine, it is $94.1 \%$. The cycle efficiency is about $21 \%$ with regenerator effectiveness of $92 \%$.

\section{CONCLUSIONS}

For this nominal operation proposed by (GALLO; EL-GENK, 2009), it was possible to observe the transient-state for all components, and large temperature and power variations.

The temperature, in the steady-state, for compressor was $573.4 \mathrm{~K}$ and turbine was $1000.1 \mathrm{~K}$ and turbine supplies $128.38 \mathrm{~kW}$, being $72 \%$ consumed by compressor. About $33.53 \mathrm{kWe}$ is available to use electric system. The BRU's behavior showed performance dependence between compressor and turbine, as it's possible to note in the temperature and power results, because of the shaft model. Hence, the polytrophic efficiency was established $86.4 \%$ for compressor and $94.1 \%$ for turbine. 
For source, the temperature in the steady-state was $1139.1 \mathrm{~K}$ and for sink, it was $472.9 \mathrm{~K}$. The temperature in the steady-state for recuperator was $604.3 \mathrm{~K}$ for the hot leg and $967.8 \mathrm{~K}$ for the cold leg. But, for recuperator, rework is needed, because they don't change sufficient heat according to (GALLO; EL-GENK, 2009), being its effectiveness of $92 \%$.

\section{ACKOWLEDGMENTS}

This research is sponsored by the Institute of the Advanced Studies' Nuclear Energy Division together the financial support of Ministry of Defense (V01010109) and Air Force Command for TERRA project.

\section{REFERENCES}

ANGELO JR., J. A.; BUDEN, D. Space Nuclear Power. $1^{\text {a }}$ ed. ORBIT - A Foundation Series, 1985.

BAKER, K. W. A New Thermodynamic Power Conversion Cycle and Heat Engine for Space Power Applications. In: SPACE TECHNOLOGY AND APPLICATIONS INTERNATIONAL FORUM, 2004, Albuquerque. Annals...Albuquerque: AIAA, 2004 . p. 680-687.

BALACHANDRAN, P. Fundamentals of Compressible Fluid Dynamics. 1. ed. Eastern Economy Edition, 2006.

BRADHORST JR, H. W. Technologies. Disponível em: $<$ http://www.nss.org/settlement/nasa/spaceresvol2/technologies.html $>$. Last acessed: 28 jun. 2017.

BRAZ FILHO, F. A. et al.indicar demais autores. Assessment of RELAP5 matrix solvers for a two-phase natural circulation loop. Annals of Nuclear Energy, v. 105, p. 249-258, 2017. 
FISHER, J. E.; DAVIS, C. B. RELAP5-3D Compressor Model. In: SPACE NUCLEAR CONFERENCE, 2005, San Diego. Annals...San Diego: Idaho National Laboratory, 2005.

GALLO, B. M.; EL-GENK, M. S. Brayton rotating units for space reactor power systems. Energy Conversion and Management, v. 50, n. 9, p. 2210-2232, 2009.

INCROPERA, F. P.; DEWITT, D. P. Fundamentals of Heat and Mass Transfer. Seventh ed. John Wiley \& Sons, 2011.

JOYNER II, C. R.; FOWLER, B.; MATTHEWS, J. A Closed Brayton Power Conversion Unit Concept for Nuclear Electric Propulsion for Deep Space Missions. In: SPACE TECHNOLOGY AND APPLICATIONS INTERNATIONAL FORUM, 2003. Albuquerque. Annals... Albuquerque: AIAA, 2003 . p. 677-684.

MASON, L. S. A comparison of Brayton and Stirling space nuclear power systems for power levels from 1 kilowatt to 10 megawatts. In: SPACE TECHNOLOGY AND APPLICATIONS INTERNATIONAL FORUM, 2001. Albuquerque. Annals...Albuquerque: AIAA, 2001 . p. 1017-1022.

RIBEIRO, G. B.; BRAZ FILHO, F. A.; GUIMARÃES, L. N. F. Thermodynamic analysis and optimization of a Closed Regenerative Brayton Cycle for nuclear space power systems. Applied Thermal Engineering, v. 90, p. 250-257, 2015.

SNYDER, N. Space Power Systems. $1^{\text {a }}$ ed. New York: Academic Press, 1961.

STINE, G. H. Space Power. 1981. Disponível em: <www.nss.org/settlement/ssp/spacepower/index.html>. 
THE RELAP5-3D CODE DEVELOPMENT TEAM. RELAP5-3D @ Code Manual Volume I: Code Structure, System Models, and Solution Methods. Idaho: INL, 2013. 645 p.

THE RELAP5-3D CODE DEVELOPMENT TEAM. RELAP5-3D C Code Manual Volume II : User's Guide. Idaho: INL, 2013. 192 p.

VAN WYLEN, G. J.; SONNTAG, R. E. Fundamentals of Classical Thermodynamics, $1^{\text {rd }}$ ed. New Jersey: Wiley, 1994

WONG, R. Y.; KLASSEN, H. A.; EVANS, R. C. Turbine and Compressor performance of a Brayton Rotating Unit during Hot Closed-Loop Operation. Cleveland: NASA, 1971. 30p.

WRIGHT, S. A.; FULLER, R.; LIPINSKI, R. J. Sandia closed brayton cycle test loop description and test results. In: SPACE NUCLEAR CONFERENCE, 2005, San Diego. Annals...San Diego: Sandia National Laboratory, 2005. p. 804-811. 